Pengaruh Motivasi Intrinsik, Gaya Kepemimpinan Transformasional...(Rizky Dan Hermin)

\title{
PENGARUH MOTIVASI INTRINSIK, GAYA KEPEMIMPINAN TRANSFORMASIONAL, DAN SEMANGAT KERJA TERHADAP KINERJA ANGGOTA MANDOR KEAMANAN PERUM PERHUTANI KESATUAN PEMANGKUAN HUTAN BALAPULANG KABUPATEN TEGAL
}

\author{
Rizky Fawzi Dwi Aryanto \\ Universitas Muhammadiyah Purwokerto \\ Hermin Endratno \\ Universitas Muhammadiyah Purwokerto
}

\begin{abstract}
Tujuan dari penelitian ini adalah untik mrnrgrtahui pengaruh motivasi intrinsik, gaya kepemimpinan transformasional, dan semangat kerja terhadap kinerja anggota mandor keamanan Perum Perhutani Kesatuan Pemangkuan Hutan Berpulang Kabupaten Tegal.

Dalam penelitian ini, peneliti melakukan pengambilan data dengan penyebaran kuesioner, dengan menggunakan metode teknik random sampling. Jumlah sampel sebanyak 124 responden. Analisis datanya menggunakan SPSS for windows versi 17. Data yang telah memenuhi uji validitas, uji reliabilitas, dan uji asumsi klasik diolah sehingga menghasilkan persamaan regresi.

Variabel dependent kinerja, dan variabel independent motivasi intrinsik, gaya kepemimpinan transformasional, semangat kerja. Hasil uji t menunjukkan bahwa variabel motivasi intrinsik, gaya kepemimpinan transformasional, dan semangat kerja berpengaruh positif signifikan terhadap kinerja. Berdasarkan uji $\mathrm{F}$ dapat diketahui bahwa variabel motivasi intrinsik, gaya transformasional dan semangat kerja berpengaruh secara simultan terhadap kinerja. Dengan melihat nilai unstandardized coefficient $B$ variabel gaya kepemimpinan memiliki nilai paling besar yaitu 0,230 artinya variabel gaya kepemimpinan transformasional memiliki pengaruh paling besar terhadap kinerja anggota. Nilai Adjusted $\mathrm{R}$ square sebesar 0,380 berarti variabel motivasi intrinsik, gaya kepemimpinan transformasional, dan semangat kerja menentukan kinerja sebesar 38\% sedangkan sisanya sebesar $62 \%$ dipengaruhi faktor lain yang tidak diteliti dalam penelitian ini.

Kata kunci: Motivasi Intrinsik, Gaya Kepemimpinan transformasional, Semangat Kerja, Kinerja.
\end{abstract}

\section{PENDAHULUAN}

\section{LATAR BELAKANG}

Kinerja organisasi akan sangat ditentukan pleh unsur pegawainya, Oleh karena itu dalam mengukur kinerja suatu organisasi sebaiknya diukur dalam tampilan kerja dari pegawainya. Penilaian kinerja pegawai lingkungan Dephut dilakukan dengan menggunakan DP3 (Daftar Penggunaan Pelaksanaan Pekerjaan). Hal ini berdasarkan SK Menhut No.810/KPTS.II/1991 tanggal 30 oktober 1991 tentang penggunaan DP 3 (Daftar Penggunaan Pelaksanaan Pekerjaan) bagi pegawai lingkungan Dephut. Kinerja yang tinggi sangat diperlukan dalam organisasi untuk melaksanakan pekerjaan secara optimal. 
Dalam susunan organisasi Perum Perhutani dibagi menjadi dua bagian yaitu bagian teknik kehutananan dan bagian non-teknik kehutanan. Bagian non-teknik kehutanan adalah bagian yang ada didalam kantor. Sedangkan bagian teknik kehutanan adalah bagian para pegawai diluar kantor dan terjun langsung ke dalam hutan. Pada bagian teknik kehutanan ini terdapat pekerjaan yang sungguh sangat menarik dan menantang yang dan sangat memacu adrenalin disaat melaksanakan tugasnya yaitu tugas seorang anggota mandor keamanan.

Dalam melaksanakan tugasnya, seorang anggota mandor keamanan hutan banyak mengalami berbagai tantangan dan rintangan dalam bertugas. Seorang anggota mandor keamanan bertugas menjaga hutan seluas 375 Hektar dengan tangan kosong dan sering kali mereka menemui pencuri kayu yang bersenjata, berbadan kekar dan berkelompok. Belum lagi ketika memasuki hutan hujan lebat dan bertemu binatang buas. Untuk itu, perlu adanya motivasi yang sangat tinggi, kepemimpinan dari atasan yang bagus, dan semangat kerja yang tinggi menjalankan tugas dan meningkatkan kinerja seorang pegawainya terutama bagi pegawai yang bertugas tantangan dan penuh resiko dalam melaksanakan tugasnya.

Dengan melihat kondisi diatas, banyak hal yang mempengaruhi kinerja anggota mandor keamanan dalam melaksanakan tugasnya. Akan tetapi, mengingat keterbataan penulis untuk mengupas seluruh faktor yang mempengaruhi kinerja, maka setelah dilakukan studi awal pada objek penelitian kepada Perum Perhutani Kesatuan Pemangkuan Hutan Balapulang, maka penulis hanya membatasi tiga variabel bebas yaitu motivasi intrinsik, gaya kepemimpinan transformasional, dan semangat kerja.

\section{PERUMUSAN MASALAH}

1. Apakah terdapat pengaruh motivasi intrinsik, gaya kepemimpinan transformasional, dan semangat kerja secara parsial terhadap kinerja anggota mandor keamanan di Perum Perhutani Kesatuan Pemangkuan Hutan Balapulang?

2. Apakah terdapat pengaruh motivasi intrinsik, gaya kepemimpinan transformasional, dan semangat kerja secara simultan terhadap kinerja anggota mandor keamanan di Perum Perhutani Kesatuan Pemangkuan Hutan Balapulang?

\section{TUJUAN PENELITIAN}

1. Untuk menganalisis pengaruh motivasi intrinsik, gaya kepemimpinan transformasioanal, dan semangat kerja secara parsial terhadap kinerja anggota mandor keamanan Perum Perhutani KPH Balapulang Kabupaten Tegal.

2. Untuk menganalisis pengaruh motivasi intrinsik, gaya kepemimpinan transformasional, dan semangat kerja secara simultan terhadap kinerja anggota mandor keamanan Perum Perhutani KPH Balapulang Kabupaten Tegal.

\section{TINJAUAN PUSTAKA}

\section{a. MOTIVASI INTRINSIK}

Teori motivasi yang dikembangkan oleh Hezberg dikenal dengan model dua faktor dari motivasi, yaitu faktor motivasional dan faktor hygiene atau pemeliharaan. 
Menurut teori ini yang dimaksud faktor motivasional adalah hal-hal yang mendorong berprestasi yang sifatnya intrinsik, yang berarti bersumber dalam diri seseorang, sedangkan yang dimaksud dengan faktor hygiene atau pemeliharaan adalah faktor faktor yang sifatnya ekstrinsik yang berarti bersumber dari luar diri yang turut menentukan perilaku seseorang dalam kehidupan seseorang. Menurut Hezberg, Faktor Intrinsik yaitu faktor daya dorong yang timbul dari dalam diri masing-masing karyawan, berupa :

1. Pekerjaan itu sendiri (the work it work self)

2. Kemajuan (advancement)

3. Tanggung jawab (responsibility)

4. Pengakuan/Penghargaan (recognition)

\section{b. GAYA KEPEMIMPINAN TRANSFORMASIONAL}

Kepemimpinan Transformasional yaitu pemimpin yang mencurahkan perhatiannya kepada persoalan-persoalan yang dihadapi oleh para pengikutnya dan kebutuhan pengembangan dari masing-masing pengikutnya dengan cara memberikan semangat dan dorongan untuk mencapai tujuannya (Robbins, 2007).

Adapun indikator gaya kepemimpinan transformasional menurut Robbins 2007:Visi dan misi, menanamkan kebanggaan, meraih penghormatan dan kepercayaan.

1. Mengkomunikasikan harapan tinggi, menggunakan symbol untuk memfokuskan pada usaha, menggambarkan maksud penting secara sederhana.

2. Mendorong intelegensi, rasionalitas dan pemecahan masalah secara hati-hati.

3. Memberikan perhatian pribadi, melayani secara pribadi, melatih dan menasehati.

\section{c. SEMANGAT KERJA}

Davis (2000) mengemukakan semangat kerja adalah suasana kerja yang positif yang terdapat dalam suatu perusahaan dan terungkap dalam sikap individu maupun kelompok yang mendukung seluruh aspek kerja termasuk di dalam lingkungannya, kerjasama dengan orang lain yang secara optimal sesuai dengan kepentingan dan tujuan perusahaan.

Nitisemito (2002) mengatakan bahwa semangat kerja adalah melakukan pekerjaan secara lebih giat, sehingga dengan demikian pekerjaan akan dapat diharapkan lebih cepat dan lebih baik.

Menurut Benge (1990) indikator untuk mengukur semangat kerja pegawai yakni sebagai berikut:

1. Jenis pekerjaan.

2. Kemampuan melakukan pekerjaan.

3. Suasana fisik lingkungan kerja.

4. Hubungan dengan rekan sekerja.

5. Sikap terhadap imbalan.

\section{d. KINERJA}

Menurut Mangkunegara (2001), kinerja adalah hasil kerja secara kualitas dan kuantitas yang dapat dicapai oleh seorang pegawai dalam melaksanakan tugas sesuai dengan tanggung jawab yang diberikan kepadanya.

Indikator kinerja menurut Gomes (2003) yaitu: 
Pengaruh Motivasi Intrinsik, Gaya Kepemimpinan Transformasional...(Rizky Dan Hermin)

1. Quantity of work: jumlah kerja yang dilakukan dalam suatu periode yang ditentukan.

2. Quality of work: kualitas kerja yang dicapai berdasarkan syarat-syarat kesesuaian dan kesiapannya.

3. Job Knowledge: luasnya pengetahuan mengenai pekerjaan dan keterampilannya.

4. Creativeness: keaslian gagasan-gagasan yang dimunculkan dan tindakantindakan untuk menyelesaikan persoalan-persoalan yang timbul.

5. Cooperation: kesediaan untuk bekerjasama dengan orang lain atau sesama anggota organisasi.

6. Dependability: kesadaran untuk dapat dipercaya dalam hal kehadiran dan penyelesaian kerja.

\section{METODE PENELITIAN}

Jenis penelitian yang digunakan dalam penelitian ini adalah metode survey yaitu penelitian yang mengambil sampel dari satu populasi dan menggunakan kuisioner sebagai alat pengumpul data yang pokok. Instrumen pengumpulan data yang digunakan dalam penelitian ini adalah kuesioner yang berisi butiran-butiran pertanyaan yang berkaitan dengan indikator-indikator yang ada pada variabel-variabel.

Populasi dalam penelitian ini adalah seluruh anggota mandor keamanan di Perum Perhutani Kesatuan Pemangkuan Hutan Balapulang yang berjumlah 180 orang dengan sampel 124 karyawan dan di hitung dengan menggunakan rumus Slovin dan dalam pengambilan sampel menggunakan teknik random sampling.

Data yang digunakan dalam penelitian ini adalah data kuesioner yang diperoleh dan diisi oleh responden yang dijadikan sampel dalam penelitian. Untuk mengetahui ada tidaknya hubungan antara variabel dependen dengan variabel independen baik secara parsial maupun simultan, maka digunakan teknik analisis regresi linier berganda serta uji $F$ dan $t$. Adapun model matematika dari regresi ini adalah sebagai berikut :

$$
Y=a+b_{1} X_{1}+b_{2} X_{2}+b_{3} X_{3}+e
$$

Dimana:

$$
\begin{array}{ll}
Y & : \text { Kinerja } \\
a & : \text { Konstanta } \\
\mathrm{b}_{1} \mathrm{~b}_{2} \mathrm{~b}_{3} & : \text { Koefisien Regresi } \\
\mathrm{X}_{1} & : \text { Motivasi intrinsik } \\
\mathrm{X}_{2} & : \text { Gaya Kepemimpinan Transformasioanal } \\
\mathrm{X}_{3} & : \text { Semangat Kerja } \\
\mathrm{e} & : \text { standar eror }
\end{array}
$$

\section{ANALISIS DATA DAN PEMBAHASAN}

\section{a. ANALISIS DATA}

Semua data pada setiap item pertanyaan kuesioner dinyatakan valid dan reliabel. Hasil penelitian ini menunjukkan bahwa asumsi klasik model regresi sudah terbebas dari permasalahan normalitas, multikolinieritas, heteroskedastisitas sehingga model regresi sudah tepat digunakan dalam pengujian hipotesis dalam penelitian ini. 


\section{b. PEMBAHASAN}

Data yang diperoleh dari 124 responden yang telah mengisi kuesioner secara lengkap, selanjutnya dianalisis dengan hasil pada tabel sebagai berikut:

Tabel Hasil uji regresi linier berganda antara variabel-variabel motivasi intrinsik, gaya kepemimpinan transformasional, dan semangat kerja terhadap kinerja

\begin{tabular}{|l|l|l|l|}
\hline Variabel & $\mathrm{B}$ & $\mathrm{t}$ & $\mathrm{Sig}$ \\
\hline Konstanta & 1.811 & 5.858 & 0.000 \\
\hline Motivasi Intrinsik (X1) & 0.216 & 5.686 & 0.000 \\
\hline Gaya Kepemimpinan Transformasional (X2) & 0.230 & 5.784 & 0.000 \\
\hline $\begin{array}{l}\text { Semangat Kerja (Y) Adj } \mathrm{R}=0,380 \\
\mathrm{R} \text { Square }=0.395 \quad 0.152\end{array}$ & 6.008 & 0.000 \\
$\mathrm{~F}_{\text {hitung }}=26.110$ & $\mathrm{~F}_{\text {tabel }}=2,68 \mathrm{p}=0.000$ & \\
\hline
\end{tabular}

Persamaan regresi untuk mengestimasi variabel terikat dengan menggunakan seluruh variabel bebas adalah sebagai berikut:

$\mathrm{Y}=1.811+0.216 \mathrm{X}_{1}+0.230 \mathrm{X}_{2}+0.152 \mathrm{X}_{3}$

Keterangan:

Y : Kinerja

$\mathrm{X}_{1} \quad$ : Motivasi Intrinsik

$\mathrm{X}_{2} \quad$ : Gaya Kepemimpinan Transformasional

$\mathrm{X}_{3} \quad$ : Semangat Kerja

E : Standar Error

Berdasarkan tabel pengujian secara parsial diperoleh hasil $t_{\text {hitung }} X_{1}=5,686$ dengan nilai signifikansi sebesar 0,000 berarti Motivasi Intrinsik secara parsial berpengaruh signifikan terhadap kinerja, ditunjukan dengan pengujian hipotesisnya bahwa pengaruh motivasi intrinsik diterima, berarti variabel motivasi intrinsik mempengaruhi kinerja anggota mandor keamanan Perum Perhutani Kesatuan Pemangkuan Hutan Balapulang. Penelitian ini sejalan dengan penelitian yang dilakukan oleh Hendriyanto (2006) dengan judul Pengaruh Motivasi Intrinsik, Ekstrinsik Terhadap Kinerja Karyawan (Studi Pada Perum Bulog Sub Drive Surabaya Selatan) dengan hasil penelitian motivasi intrinsik dan ekstrinsik secara simultan

Secara parsial $t_{\text {hitung }} X_{2}=5,784$ dengan nilai signifikansi sebesar 0,000 berarti Gaya kepemimpinan transformasional berpengaruh signifikan terhadap kinerja anggota mandor keamanan Perum Perhutani Kesatuan Pemangkuan Hutan Balapulang. Penelitian ini sejalan dengan penelitian yang dilakukan oleh (Devi 2005) dengan judul Pengaruh Gaya Kepemimpinan Transformasioanal Terhadap Kinerja Karyawan PT.Bank CIMB Niaga Bagian Marketing Lending di Surabaya dengan hasil penelitian kepemimpinan transformasioanal berpengaruh positif signifikan terhadap kinerja karyawan.

Secara parsial $t_{\text {hitung }} X_{3}=6,008$ dengan nilai signifikansi sebesar 0,000 berarti Semangat kerja berpengaruh signifikan terhadap kinerja anggota mandor keamanan Perum Perhutani Kesatuan Pemangkuan Hutan Balapulang. Penelitian ini sejalan dengan 
penelitian Nurhendari (2007) dengan judul Pengaruh Stres Kerja Dan Semangat Kerja Terhadap Kinerja Karyawan Bagian Produksi (Studi kasus pada CV. Aneka Ilmu Semarang) dengan hasil penelitian variabel stress kerja tidak berpengaruh terhadap kinerja, sedangkan variabel semangat kerja berpengaruh signifikan terhadap kinerja.

Berdasarkan pengujian secara simultan pada tabel dapat dapat diketahui bahwa nilai $F_{\text {hitung }}$ sebesar 26, 110 sedangkan df $(124-3)=121$ dan $F_{(0,05 ; 121)}$ sebesar 2,68 dengan nilai signifikansi 0,000 . Karena nilai $F_{\text {hitung }}>F_{\text {tabel }}(26,110>2,68)$ sehingga $H_{0}$ ditolak dan $H_{a}$ diterima yang berarti ada pengaruh signifikan secara bersama-sama (simultan) variabel motivasi intrinsik $\left(X_{1}\right)$, gaya kepemimpinan transformasional $\left(X_{2}\right)$, dan semangat kerja $\left(X_{3}\right)$ terhadap (Y).

Nilai Adjusted Rsquare sebesar 0,380 (38\%) hal ini berarti variabel motivasi intrinsik, gaya kepemimpinan transformasional, dan semangat kerja menentukan kinerja sebesar $38 \%$, sedangkan sisanya $62 \%$ dipengaruhi oleh faktor lain yang tidak diteliti dalam penelitian ini.

\section{KESIMPULAN DAN SARAN}

\section{a. KESIMPULAN}

1. Motivasi intrinsik secara parsial berpengaruh signifikan terhadap kinerja anggota mandor keamanan. Hal ini ditunjukkan dengan nilai $t_{\text {hitung }}$ sebesar 5,686 lebih besar dari $t_{\text {tabel }}$ sebesar 1,960 .

2. Gaya kepemimpinan transformasional secara parsial paling berpengaruh signifikan terhadap kinerja anggota mandor keamanan Perum Perhutani Kesatuan Pemangkuan Hutan Balapulang. Hal ini ditunjukkan dengan nilai $t_{\text {hitung }}$ sebesar 5,784 lebih besar dari $t_{\text {tabel }}$ sebesar 1,960.

3. Semangat kerja secara parsial berpengaruh signifikan terhadap kinerja anggota mandor keamanan Perum Perhutani Kesatuan Pemangkuan Hutan Balapulang. Hal ini ditunjukkan dengan nilai $t_{\text {hitung }}$ sebesar 6,008 lebih besar dari $t_{\text {tabel }}$ sebesar 1,960.

4. Motivasi intrinsik, gaya kepemimpinan transformasional dan semangat kerja secara simultan berpengaruh signifikan terhadap kinerja anggota mandor keamanan Perum Perhutani Kesatuan Pemangkuan Hutan Balapulang. Hal ini ditunjukkan dengan nilai $F_{\text {hitung }}$ sebesar 26.110 lebih besar dari $F_{\text {tabel }}$ sebesar 2,68.

\section{b. SARAN}

Untuk lebih meningkatkan pengaruh positif terhadap kinerja secara maksimal pihak Perum Perhutani Kesatuan Pemangkuan Hutan Balapulang:

1. Bagi pihak Perum Perhutani Kesatuan Pemangkuan Hutan Balapulang, dapat meningkatkan atau mempertahankan motivasi intrinsik, gaya kepemimpinan transformasional dan semangat kerja karena variabel tersebut baik secara simultan maupun parsial berpengaruh signifikan terhadap kinerja.

2. Pihak Perum Perhutani Kesatuan Pemangkuan Hutan Balapulang hendaknya lebih memperhatikan kebijakan yang berkaitan dengan variabel gaya kepemimpinan transformasional. Karena dalam penelitian terbukti bahwa variabel tersebut paling berpengaruh terhadap kinerja. Langkah konkret yang dilakukan adalah memilih pemimpin yang bertanggung jawab, berani, tegas, peduli terhadap bawahannya, dan cepat dalam mengambil keputusan. 
Pengaruh Motivasi Intrinsik, Gaya Kepemimpinan Transformasional...(Rizky Dan Hermin)

3. Bagi peneliti selanjutnya, sebaiknya menambah variabel lain misalnya motivasi ekstrinsik, pengembangan karir dan lingkungan kerja atau dengan mengubah variabel dependennya.

\section{DAFTAR PUSTAKA}

Ali, Eko Maulana. 2012. Kepemimpinan Transformasional Dalam Birokrasi Pemerintahan. Edisi Pertama. Jakarta: PT.Multicerdas Publishing

Algifari, 2000.Analisis Regresi: Teori, kasus, dan solusi. Edisi Kedua. Yogyakarta: BPFE

Arikunto, Suharsini.2002. Prosedur Penelitian suatu Pendekatan Praktek, Edisi Revisi V Cetakan Ke Dua Belas.Bandung: Rineka Cipta.

Agus.2008.Pengaruh Motivasi Dan Disiplin Kerja Terhadap Kinerja Pegawai (Studi kasus kantor pelayanan pajak Badan Usaha Milik Negara)

Anaroga, Panji.1993. Manajemen Bisnis. Jakarta: Rineka Cipta

Awat, N. J. 1995. Manajemen keuangan, Jakarta: PT Gramedia Pustaka Utama

Baron dan Amstrong. 1989. Behavior in Organization Understanding and Managing The Human Side of Work. Prentice Hall. New Jersey

Benge, EJ. 1990. Measuring Moral Key to increased Productivity. Modern Bussines Report. New York : Mc Millan Publishing. Co, Inc

Davis, Keith and John W. Newstrom. (1985). Human Behavior at Work : Organizational Behavior. Mc, Graw-Hill Inc., New York

2000.Perilaku Dalam Organisasi, Edisi Ketujuh, Jakarta: Erlangga

Devi.2005. Pengaruh Gaya Kepemimpinan Transformasioanal Terhadap Kinerja Karyawan PT Bank CIMB Niaga Bagian Marketing Lending Di Surabaya

Fahmi.2009. Analisis Pengaruh Gaya Kepemimpinan Dan Motivasi Kerja Terhadap Kinerja Pegawai SPBU Pandanaran Semarang.

Friedman, M.M. Bowden. 2003. Teori Penelitian dan Praktek.Edisi kelima. New Jersey: Yogyakarta

Gibson, James L. et.al.1987.Organization, Behavior, Structure, Processes. $4^{\text {th }}$ ed, Richard D. Irwin Inc.

Ghozali, Imam. 2001. Model Persamaan Konsep dan Aplikasi dengan Program AMOS ver 15.0. Badan Penerbit Universitas Diponegoro: Semarang

2007.Aplikasi Analisis Multivariat dengan Program SPSS. Penerbit Universitas Diponegoro: Semarang 
Pengaruh Motivasi Intrinsik, Gaya Kepemimpinan Transformasional...(Rizky Dan Hermin)

Gomes, Faustino Cardoso, 2010.Manajemen Sumber Daya Manusia. Jogjakarta: CV Andi Offset

2003.Manajemen Sumber Daya Manusia. Jogjakarta : CV. Andi Offset

Hendriyanto. 2016. Pengaruh Motivasi Intrinsik, Ekstrinsik Terhadap Kinerja Karyawan (Studi pada Perum Bulog Sub Divre Surabaya Selatan)

Ilyas, 2001. (http:/jurnal-sdm.blogspot.com/2009/09/indikator-untuk-mengukur-kinerja.html.

Ibrahim,2004.Perilaku Organisasi.Jakarta:Sinar Baru Aglesindo

Kasmino.2012.Kontribusi Semangat Kerja, Komitmen dan Motivasi Berprestasi Terhadap Kinerja Guru SDN Di wilayah UPT Pendidikan Kecamatan Pelaihari Kabupaten Tanah Laut.

Mangkunegara, AP. 2001. Manajemen Sumber Daya Manusia. Cetakan Pertama, Rosda, Bandung.

Marwansyah, 2010.Manajemen Sumber Daya Manusia.Bandung : Alfabeta

Maulizar. 2012. Pengaruh Kepemimpinan Transaksional Dan Transformasional Terhadap Kinerja Karyawan Bank Syariah Mandiri Cabang Banda. Jurnal ilmu manajemen, Volume I, Tahun I, No. I, Agustus

Nurhendari Siti. 2007. Pengaruh Stres Kerja Dan Semangat Kerja Terhadap Kinerja Karyawan Bagian Produksi (Studi Kasus Pada CV. Aneka IImu Semarang )

Nitisemito, Alex S. 1982. Manajemen Personalia (MSDM). Jakarta: Ghalia Indonesia. 1996. Manajemen Personalia. Yogyakarta: Universitas Gajah Mada. 2002.Manajemen Personalia.Cetakan ke-8.Jakarta: Ghalia Indonesia

Notoatmodjo, S. 2010. Metodologi Penelitian Kesehatan. Jakarta : Rineka Cipta

Pattanayak, B. 2002.Human Resource Management.New Delhi: Prentice Hall Of India

Purwanto S.K, Suharyadi, 2004. Statistika untuk ekonomi dan keuangan modern. Jakarta: PT.Salemba Empat

Purnomo,Joko. 2007. Pengaruh Kepemimpinan, Motivasi, Dan Lingkungan Kerja terhadap Kinerja Pegawai Negeri Sipil Pada Dinas Kehutanan dan Perkebunan Kabupaten Jepara.

Rivai, Veithzal .2004. Manajemen Sumber Daya Manusia untuk Perusahaan Dri Teori ke Praktik. Jakarta:PT Raja Grafisindo Persada

Robbins, Stephen P. 1996. Perilaku Organisasi -Konsep, Kontroversi, Aplikasi Jakarta : PT Indeks Gramedia Grup. 
Pengaruh Motivasi Intrinsik, Gaya Kepemimpinan Transformasional...(Rizky Dan Hermin)

2002.Prinsip-Prinsip Perilaku Organisasi. Edisi kelima, Erlangga, Jakarta.

2007.Perilaku Organisasi, Edisi 10. Pearson Education, Inc, Upper saddle Rive, New Jersey.Yogyakarta: Indeks.

Siagian, S.P .2000. Manajemen Sumber Daya Manusia. Edisi kesatu, cetakan kedelapan, Bumi Aksara, Jakarta.

2007.Manajemen Sumber Daya Manusia. Jakarta : Bumi Aksara.

Singarimbun, Masri, dan Sofian Effendi. 1998. Metode Penelitian Survai. Jakarta: LP3ES.

Sutojo, siswanto. 2001. Menyusun Strategi Harga. Damar Mulia, Jakarta.

Soetrisno,asrip.2008. keamanan hutan. Madiun: Pusat Pendidikan Dan Pelatihan SDM Perum Perhutani

Yukl Gary, 2010.Kepemimpinan Dalam Organisasi. Jakart: PT indeks 